\title{
SACRAMENT AS A CULTURAL TRAIT IN RAJVAMSHI COMMUNITY OF NEPAL
}

\author{
Prof. Dr. Som Prasad Khatiwada \\ Post Graduate Campus, Biratnagar \\ khatiwadasom@yahoo.co.in
}

\begin{abstract}
Rajvamshi is a local ethnic cultural group of eastern low land Nepal. Their traditional villages are scattered mainly in Morang and Jhapa districts. However, they reside in different provinces of West Bengal India also. They are said Rajvamshis as the children of royal family. Their ancestors used to rule in this region centering Kuchvihar of West Bengal in medieval period. They follow Hinduism. Therefore, their sacraments are related with Hindu social organization. They perform different kinds of sacraments. However, they practice more in three cycle of the life. They are naming, marriage and death ceremony. Naming sacrament is done at the sixth day of a child birth. In the same way marriage is another sacrament, which is done after the age of 14. Child marriage, widow marriage and remarriage are also accepted in the society. They perform death ceremony after the death of a person. This ceremony is also performed in the basis of Hindu system. Bengali Brahmin becomes the priests to perform death sacraments. Shradha and Tarpana is also done in the name of dead person in this community.
\end{abstract}

Keywords: Maharaja, Thana, Chhati, Panju and Panbhat.

\section{Introduction}

Rajvamshi is a cultural group of people which reside in Jhapa and Morang districts of eastern Nepal. They were called Koch or Koche before being introduced by the name Rajvamshi. According to CBS data 2011, their total number is 115242 including 56411 males and 58831 females. However, the number of Rajvamshi Language speaking people is 122214, which is more than the total number this group. Therefore, it is clear that other groups of people in a little number also speak this language who are residing with Rajvamshi community. In the beginning, Koches were aboriginal tribes of Northern India (Risley, 1891: 
492). They were able to get political power in western Brahmaputra valley of Assam in early $16^{\text {th }}$ century (Nath, 1989: 1). Biswa Singh the Koche chief was responsible to organize the strength of his tribe. In the beginning, Ala-ud-din Hussein Shah the Sultan of Bengal used to rule there (1439-1510AD) and Biswa Singh was his chief. Biswa Singh established the foundation of his kingdom in $1515 \mathrm{AD}$ at Kamata. His son was Naranarayan ((1540-1587 AD). His brother Chilarai was very clever and Naranarayan become able to flourish the religion Vaisnavism in whole Kochaland. However, his brother Chilarai died in 1576 and the Kocha kingdom was divided in to two parts from 1581 AD (Ibid: 2). The western division was Koch Bihar and the eastern was Koch-Hajo in this division. After that, this kingdom was in existence up to $1826 \mathrm{AD}$.

Kochas include Meche, Kacharies, Bodos and Rajvamsis etc. However, there is a great controversy about their origin. They are said the people of Dravidian group of Bengal (Risley, 1891: 491). Some other scholars have categorized them as Mongoloid group (Waddel, 1975: 48). Minhas-ud.din Siraj is the author of Taba Kat-i-Nasiri, which contains the account of Muha-mmad-bin-Bhaktiyar-Bhalji to the kingdom Kamrup in the first part of the $13^{\text {th }}$ century noted that there were some people by Kunch (Koch), Mej (Mech) and Tihar (Tharu) having top countenance (Nath, 1989:3). The Yogini Tantra, which was composed in Assam in 16th century, refers that Koches were born from a Mecha women. The Dharma Purana compiled in Assam in $17^{\text {th }}$ century says that the Koches used to kill all kind of creatures and used to take even beef (Ibid, 4). In conclusion, it is said that they were Mongolian people who came down in Brahmaputra valley from Tibet and mixed with Dravidian and other groups of people. Therefore, they started to follow Hinduism and other sacraments as Bodo and other groups accepted.

Koches are divided in to Rajvamshi and Bhanga Kshatriya. Koches were said as Rajvamshis after their conversion to Hinduism (Bhattacharya, 1929:21). However, we do not have any evidences to tell them as Rajvamshi. The Darrang Raj Vamsavali (Genealogy) is the genealogy of Koch royal family, which was written in $18^{\text {th }}$ century and this document does not indicate them as Rajvamshi. Instead, they are said Koche and Meche. Therefore, it is believed that when the Koches became conscious and knew the glory of their ancestors they began to call themselves as Rajvamshi meaning decedents' of the royal kinder. 
Biswa Singh was said Kshetriya by the Brahmins after establishing his rule in Assam. Then he is said the son of lord Shiva. They were said Bhanga Kshetriya in the term that their thread was cut thrown by Parsuram. They were named Bhanga Kshetriya from Brahmins after establishing their kingdom in eastern India. There is not any distinction among Koch, Rajvamshi and Paliya in their culture. Yogini Tantra said Kuvaca to Kocha and Padma Purana says Kuvacaka is the term of taking barbarian tongue and eating dirty food. It is believed that the word Meche was established from the Samskrit word Mlechchha. Kocha and the Mecha are the same group of people, because when Biswa Singh of this group was representing by 12 Mecha families, his mother was said to be a daughter of Kocha family. In other view, Koches were from Kamboja and it represents a group of people not a single caste. There was a tradition of calling Kamboja to Tibet. In this context, the people of northeast are said to be come from Tibet and Koch people are also said to be the migrant of Kamboja. At the time of $11^{\text {th }}$ century, Kocha, Mecha and Tharu tribes were seen in northeast India. This reference comes at the Bhaktiya army of Kamarupa.

\section{Origin}

Kocha kingdom was extended up to Morang in the north, Bihar in south and Assam in the east in seventeenth and eighteenth century. The influence of Kocha people was destroyed after the collation of this state in Nepal and British India (Bista, 2039: 105). They are residing in greatest number in Jhapa district. However, some Rajvamshis are residing in Morang also. Their number is greater in northern India, Bihar and west Bengal than Nepal. Kocha, Mecha and Rajvamsi are the same groups of people. The language that they speak is Tajpuriya. Rajvamshis are divided in two Sharaniya (half-Hindu Koch), Kamtali (Full Hindu), Koch, Kamtaikoch, Rajvamshi, Deshi and Polo. Their king Hajo was very famous in medieval period.

In the beginning, Kochas were Kamtali, Koch, Kamtaikoch, Rajvamshi, Deshi and Polo. After the downfall of Koche kingdom, they preferred to hide their identities. They started to follow the customs of Rajput and latter on they became Rajvamshi (Panta, 2041: 62). It is said that the same Koche are divided in to three groups. Hence, a group became Muslim, the second remained Koche and the last one became Rajvamshi (Ibid). Rajvamshis 
of Nepal claim themselves that they are related with the Mahabharata epic of Hindus. They believe that the king of Kocha kingdom was Kichak and he was their ancestor. In Prithivinagar VDC of Jhapa district, there is a pond named Kichakbadh Pokhari. They believe that Bhima the Pandava of Mahabharata epic killed Kichak in the same place. There is a hump with rich archaeological antiquities. That is said the centre of Kichaka Royal palace. Many Rajvamshi people reach there to celebrate Makarsamkranti festival per year.

Some people think that Hajos were the ancestors of Rajvamshis. They were not Hindus in the beginning. They believe that Biswasing was the first Rajvamshi who became Hindu. Hunter views that the rich and powerful people became Rajvamshi and the rest of others remained Kocha at that period. There were two regions in Kocha kingdom namely Jalpaigudhi and Kuchbihar. Both centers were ruled from the same group of people according to their view. They believe that their ancestors were Shiva, Yogini and Madhavi.

In Nepal, we can find two types of Rajvamshis. They are Bangali and Khota Rajvamshis. Bengalis are called Bonga also and they wear a black thread in their neck. However, Khota do not wear such types of ropes. They have a great discrimination between them. Each of them claims their super status than the other groups. Khotas think on the glory on telling themselves Kocha as the king. According to their view, they were only the Kocha people as the children of the Kocha king. Latter on Bengalis reached in the high power and they started to say Kocha or the children of the king themselves. This made Khota the different group than Kochas. In the same way, Khotas blame the Bengalis that they are the group of eating rotten rice. They eat Peltar rice or Panbhat, which is known as the rotten rice in their view. Hence, Khotas means the lower or having some fault. Therefore, the Bengalis blame them as the lower group in social status. Their virgin boy is called Mandal and the married one is said Bharar.

\section{Types}

According to the Rajvamshi people they have different kind of Gotras. They are divided in to Dhaneswara, Kasyap, Bharadwaj and Sandip Gotras. They do not write their Gotras and only the family name is written in their title. They say Bengali for Koche and Rajvamshi consider themselves higher than Bengali or Koche (Waddel, 1975: 48) group of 
people. In the same way, they are divided in to Khota Rajvamshi and Bangali Rajvamshi. The Khota groups are said lower than Bengali group in their social status. Bengali groups do not prefer to marry with the boys and girls of Khota Rajvamshis. However, Khota Rajvamshis do not care on such status. They care on the Gotras and Thars at the time of marriage. They prefer to marry with separate groups than the own group of people.

Rajvamshi people speak a separate kind of language called Rajvamshi language. Their language is the mixture of Hindi, Maithili, Bhojpuri and Bengali. They speak their own mother tongue while communicating each other in their own group. Nevertheless, they prefer to use Hindi and Maithili language to communicate with other groups of people. In the same way, they do not prefer to write documents in their language. However, the influence of Bengali language is more in practice than other language groups. Their mother language is called Tajpuria.

\section{Costume}

Rajvamshi people prefer to wear clothes in very low quantity. Females wear a piece of cloth from chest to the knee. In traditional way, they wear white clothes. Now women prefer to wear more clothes than traditional ones. They prefer to wear Sari, Saya and Blouse. They have different methods of wearing Sari than other group of Terai people. In the same way males wear a Dhoti with Langauti and a Bhoto (Shirt). However, rich and educated people prefer to wear more clothes. Modern lads wear pants and shirts. Modern dresses of girls like pants and shirts are also used today from the influence of other racial groups.

Rajvamshi males do not prefer to wear ornaments. However, some of them wear rings made of silver. In the same way, females wear earrings made from silver and gold. Rajvamshi women wear bangles, foot chains, finger rings and beads as their ornaments. They do not wear more ornaments in nose and ears. Rajvamshi women wear Nathiya, Kannoj, Laur, Kanmajja, Phuli and Bulaki in their nose and ear in traditional way. Hansuli, Pote and Har are their neck ornaments. Bangle, Pat, Aunthis, Kada, Kalli, Pauju and Bichchhi are other ornaments. However, they wear different kind of ornaments in neck. Hence, necklace is a main neck ornament. Rajvamshi people consider tattooing also as an ornament. Women prefer to make tattoo in their arms and backbones. The older women wear fewer ornaments 
than the younger ones. Young women wear different kind of bangles in their hands. They prefer to wear nail polish and eyeliner with lipsticks at present. Young girls prefer to wear modern ornaments than their traditional ones. They prefer to wear gold ornaments in the place of silver made items.

\section{Food habits}

Rajvamshi people prefer to stay in clean place and eat delicious and tasty food. They like fish to eat more like Bengali people. Curd, Bhuja and Pantabhat were famous among them in the past. Rajvamshi women are interested to sell Bhuja made by themselves in market places. They compulsorily needed fishes to serve to their guest. In the beginning, they did not use to keep hens and cocks in their houses. Drinking alcohol was not permitted in this community. Latter on the system of keeping hens and cocks is introduced in this group of people. In the same way, the restriction of drinking alcohol became flexible. Now, rice, Daal, vegetables, meat, fruits and bread are their main food items. They have learnt to make Bhakka and Bagiya for their festivals. Curd and sweet is compulsory in their sacramental and festival parties. The souvenir that they take with them while going to participate in the function as an invitee is also the same objects. They carry such food items while going to participate in marriage and death functions. They think that they have to take something with them as souvenirs while going somewhere to participate in the function as an invitee.

\section{Housing}

Rajvamshis are expert in making thatched roofs of the houses. They make the roofs of hey and dried grass. They decorate the thatched houses in the way that it seems very beautiful. It becomes durable also. As they live in the hot place, such roofs seem hot and cold proof. Only the male members make the roofs of the houses. In the same way, only the females do the cleaning of the houses. They do not have the system of going to the field to do agricultural work by the women. They pass most of their time in cleaning and decorating the houses. Only a few number of rich Rajvamshi people make the house with concrete and cement. Rest of other rich people also does not like to make such houses. Instead, they make more than a house in the compound. They are interested to make a storehouse separately in their compound. In general, storehouses remain round in shape. The room remains pointed at 
the top and round to the bottom. The house remains made by bamboo sticks in round shape. It is well polished with mud and secured with damp. Especially paddy is kept in such houses of this society.

Rajvamshi women are very expert in wall paintings. They polish the bamboo stick walls of the house with fine mud and make it very smooth. They polish the wall several times carefully to make it beautiful. They use some hey also to save it from the damp. Then, they make the shapes that they like. Pigeons, flowers and other leaves, trees and birds are some objects that are sketched in the wall. Shapes of the pillars, stands and some steps are also made with mud while finishing the wall. Fine slippery soil, cows dung and the chaff of paddy or wheat is also mixed to prepare the glue. It becomes durable also while preparing it in this technique. Some of Rajvamshi women make the clay mixing with the jute. They cut the jute in small pieces like the dust and mix it in the mud. Then it is used for making picture. This process helps to make the pictures durable and damp proof. They make more than 16 categories of pictures.

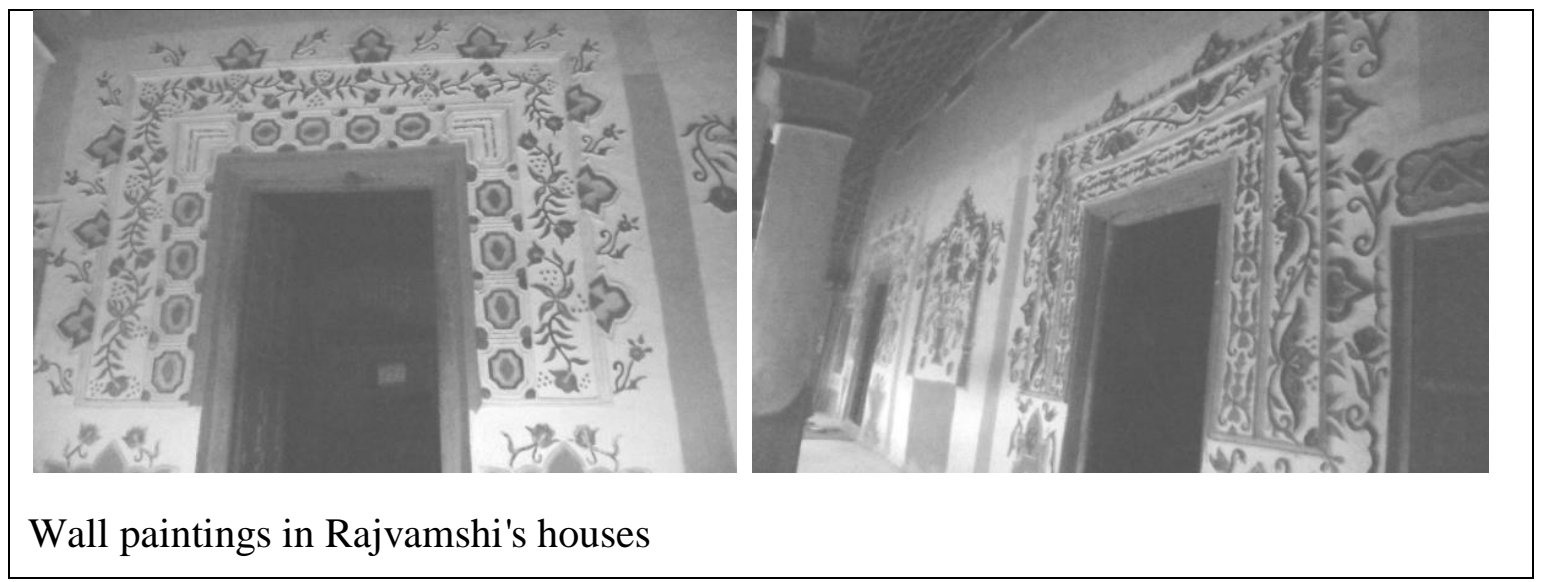

Rajvamshi women make their paintings in the wall of their houses. They make colors for paintings by themselves. Red and green colors are dominant in paintings. Old women of the family perform this duty and the younger learn such paintings from their elders. The houses are painted in the occasion of Laxmi Puja and marriage sacraments. They do not perform this duty on rainy season. They prefer to paint a house that is used as bedroom. Other 
houses are also painted, but they are not prioritized. Therefore, we can easily identify their bedrooms.

Rajvamshi people do not prefer to make idols. However, they make the image of houses and elephants to worship at the time of Siruwa Puja. They do not keep image in the Tharus of the village. Therefore, they are not expert in making mud dolls and images. Nevertheless, Rajvamshis people make baskets, ropes and other essentials by themselves. Some Rajvamshi women wear clothes by themselves. In the beginning, they used to produce cotton and make thread and clothes for their use. Nevertheless, it is said that they are not expert to make clothes and they left to make it. Except agriculture, they do not like to do other types of work.

\section{Religious beliefs}

As they are the followers of Hinduism, they worship most of Hindu deities. Ram, Krishna, Shiva, Parvati, Sita, Bishnu and Laxmi are the main deities that they worship. Now a day, many more Rajvamshis are the followers of different sects of Baisnavism. They worship the gods and goddesses of their own sect. Ramanandi, Kabir Panthis, Thakur and Tamot Panthis are some main sects that are popular in this society. Most of the sectarians are Vaisnava and they prefer to say them as Vaisnava rather than their sect. they are familiar with the devotional songs of Radhakrishna and Sita Ram. In this way, Rajvamshis are Hindus and their gods and goddesses are of Hindu origin.

Rajvamshis of Nepal have their family gods and goddesses also. Kuldevata and Gramdevatas are different in their society. The traditional gods and goddesses of Rajvamshi community are as follows.

i) Pacho Devi or Tilauli Devi: This Devi is the goddesses of the house. She is known as the Kuldevata of Rajvamshi community. She is worshipped in a corner of a room inside the house. They do not keep any images for this goddess. Instead, they keep the corner of the room clean and worship her daily with a great respect. She helps the family to remain healthy and the family remains prosperous and cheerful from her kindness. 
ii) Thakurjee: Thakurjee Devata is a great god, because Thakur means the great, respected and valuable god. There are different categories of Thakur like Thakur, Thakur Bisori, Hanuman Thakur, Thakura Devata and Kol Thakur in this community. All these words are related with the god Thakur and the way of Puja and Brata for them. Each Rajvamshi worship Hanuman Thakur and they make its Than in front of their house.

iii) Garam Sewa: It is a kind of Puja that is done at the paddy field. This Puja is done once in a year in the month of Marga. Garam Sewa is a harvesting grain Puja. Therefore, it is organized before harvesting grains. Banana, milk and rice grain is offered to the Devata in this occasion. Pigeons and kids are also massacred for this god. A party is given to the villagers and the relatives in occasion of this Puja.

iv) Guru Gosai Puja: Guru Gosai Puja is done in the occasion of some cheerful sacraments like marriage and hair cutting occasion. The Dhami (Ojha) is responsible to conduct this activity. Rajvamshi women are known untouchables at the time of menstruation. If somebody touches her in that period he becomes sick and dies in their view. However, it is harder to stay at a home without touching her. Therefore, this function is done to get rid from the sin of such touching.

v) Charak Puja: Charaka Puja is an important Puja of Rajvamshi society. This Puja is done to offer something to the gods and goddesses, who had fulfilled their desires. Chaitra month is suitable to perform this Puja. They pin a round shaped object in their leather of the body and walk around in this occasion. This person is called Diyobamshi. That person is given a present in cash. Anyone Diyobamshi, Rajvamshi, Satar and Gangai can perform this duty. However, this should be done in the memory of promised form.

\section{Main Sacraments}

\section{Some beliefs}

Rajvamshi people have some beliefs on the sacraments like other groups of people. They believe that it is not good to drink water given by pregnant women after the date of $8^{\text {th }}$ 
month of her pregnancy. In the same way, they perform a Karma of water touching and they do not drink the water given by such women whose water touching sacrament is not done after her delivery. Some Rajvamshis do not drink water given by women having a baby younger than 3 months. However, some do not believe in it and eat everything touched by women having done naming sacrament of her baby.

Rajvamshi people do not perform any sacraments for the pregnant women before the birth of a baby. However, they have some restrictions for the pregnant women and they are suppose to be followed restrict. She is not permitted to go in a long journey and cross the river at her pregnant period. In the same way, she is not sent in the ghost and lonely places. Ojha is called to make her healthy in the case of her sickness. After that other kind of rites and rituals are not done earlier than the birth of the baby.

Pregnant women do not go outside the home at night time. She is not allowed to go in death procession. The food prepared for the party of death sacrament is also not given to her. Tuesdays and Saturdays are restricted to go out for her. In the case of compulsion to go out Ojha is requested to save her from the ghost. The pregnant woman is given a thread of black color to tie it in her hand. This function is done after the third month of her pregnancy. Some people keep iron needle, knife and a net under her pillow to protect her from the ghost and evil soul. It is done for the security of the pregnant women and the baby of her womb. In the case of stomach paining before the period of delivery, it is believed that this was happened due to the effect of the god. Ojha is requested to make the god happy to release the pregnant women from its effect.

Bhutas and demons are also male and female in their belief. The male ghost is called Duwari Thakur and the female is Dien Pyatin. In the case of not getting a baby after the completion of delivery date, some mustard oil is rubbed in her stomach. Some hard Mantras are recited and the oil is given her to eat. At last, Dwari Thakur is promised to offer the pigeon and a Buti is tied in the stomach. In the same way, Bhutakali is also worshipped to get birth a baby from the pregnant woman on time. In this way, Rajvamshi people want to get the childbirth on time. However, they do not do any sacraments of a baby and a pregnant woman before the birth. 


\section{Main Sacraments}

The first sacrament that Rajvamshi people perform is Jatakarma. This is a special sacrament of the Hindus. Rajvamshi people also follow Hinduism, but they do not do Jatakarma sacrament. When the pregnant women become sick, Dagrin is requested to help her in delivering the child. She is a Chamar woman. She helps her to born baby, clean the room and wash the clothes for her. As she becomes experienced in childbirth and pregnancy, she helps the pregnant women in every event of childbirth. She rubs her stomach and suggests the way to give the birth to a baby. After the delivery process, she helps her to clean the newborn baby. The mother of a newborn baby also takes a bath and her clothes are cleaned. However, other rites are not done in this occasion. The Jatakarma rite completes in only the bathing process.

Rajvamshis do the naming Samskara of a baby after sixth day of the birth. It is called Chhathi in Rajvamshi language. This function is not done in separate way with Yajnas. At first the mother, new born baby, their room and the clothes are cleaned. Then the new born baby gets name from the eldest woman of the family. The names are given in the basis of day, month and the incidences of its birth. The names of gods and goddesses are also given to the newborn babies. There was a system of giving a name of newborn baby by the eldest women of the family in the beginning. Nevertheless, a priest with Vedic rituals does this samskaras. The barber is also invited to purify the house in Chhatti. At first, the house is cleaned and polished with cow's dung and the mud then the water of the Ganga river is sprinkled around the rooms and the house to purify it. After that, the barber cuts the nail of the mother and newborn baby. He paints the nail of the baby and the mother both. The function of Jalkumari is also done in the same day. The mother of newborn baby is requested to do some functions and go to the well and the tubewell from that day. According to a traditional system, the woman goes to the well with some oil and Sindura in her hand and offers it in the well or the tubewell. Then she brings a pot of water and drinks in the evening with the food. It is said the rite of Jalkumari.

After naming sacrament, Rajvamshi do not have the system of other sacraments to accomplish before the marriage ceremony. They do not have the system of doing rice-feeding 
sacrament for a child. The mother of the newborn baby can feed the baby whenever she wants. She feeds the baby with rice and Daal that is cooked to the family members. However, they have a custom of giving a bowl to the new born baby by it's uncle (mother's brother) in the case of seeing the teeth at first in the upper side. They do not have the system of doing different sacrament for making hole in the ear. However, the hole is made in the nose and ears of a girl in the age between 6 to 12 months. This is done for the use of ornament in this society. They do not have the sacrament for hair shaving of a baby. They cut its hair whenever they feel its need. In the case of Bhakal they cut the hair in certain places. Rajvamshi people do not have the system of doing Upanayan sacrament like other thread wearing groups. They do not wear thread in their neck and they do not need it. Therefore, other sacrament that is done after naming rite in Rajvamshi society is marriage.

The most important sacrament that Rajvamshi people perform is marriage. It is one of the most important sacraments of each society. However, the rite that is performed in this occasion is different in each society. Hence, the marriage sacrament that is done in Rajvamshi society is based on Hindu custom. The Brahmin recites different Mantras according to traditional Hindu system. They have the system of child marriage and getting marriage with multiple wives in traditional villages. Remarriage and widow marriage is also accepted in this society. They do not care Gotra and Prabar for marriage. However, they do not do marriage inside a family nearer than seven generations. Marriage of cross cousin is not accepted. Marriage system is simple and chieap. There is not any custom of Tilaka and dowry. In some circumstances, some money is given to the parents of a girl to marry her with his son. However, this system is also disappeared at present. It is done only in the form of Rita. The girls are low in number in this community. So, the boy is expected to go to the girl's house to beg her hand. They prefer to marry their son and daughter in their earlier age. Now the law against the child marriage has forced them to arrange the marriage of the youths after the age of 15 in this group.

Rajvamshi women are free for re-marriage also. After the marriage with a boy, they can do another marriage in different circumstances. If the marriage is done with misinformation, cheating and without willing of a girl, she is free to marry with other boy. However, the marriage with more than 3 to 4 persons is not considered well in this society. 
They have the system of remarriage, widow marriage, multiple wives marriage and inter-cast marriage also. Both boys and the girls of Rajvamshi community can do marriage, as they will. Therefore, they can marry with other casts people also. However, they do not like to marry with untouchable groups of people. If their daughter gets married with a untouchable boy, they do not accept them and allow to come their house again. However, they think good to get married with upper caste people like Kshetry and Brahmin. They think that Brahmins are like the gods. The girl stays at her father's home for the long time after her marriage also. If the girls die in her father's home, the boy is allowed to get marry again with another girl. However, in the case of dying a boy, the girl cannot get marry again as usual. However, she can choose a boy and can marry herself.

The system of marriage in Rajvamshi community is similar with many other groups of people. Their system is much more similar with the marriage of Satar, Dhimal and Tharu community. In the beginning, the relatives of a boy used to find out the girl whether she is suitable for marriage or not. A person does this job and he is called Aguwa. At first Aguwa proposes the willing of marriage to the girl's father. Then it comes the term of acceptance and rejection. If the proposal is accepted from the girl's father, the process goes ahead. In the process of showing both the boy and the girl each other, they are called in a certain place. If they like each other, the process goes ahead. Then it comes the term of Dekhasuni process. In this process, the boy and his relatives go to the girl's house with some gifts for the girls. Then the girl also wears the clothes and ornaments got from the boys side and comes near to the boy and his relatives. Then, they say that she is OK. In the same way, the relatives of the girl's side also go to the boy's house. They provide some clothes and ornaments to the boy. The boy also wears the clothes that is sent from the girl's side and stands in front of these people taking a plate in his hand. The souvenir taken by the people of the girl's side are given there to the boy in the plate of his hand. Then the custom of Dekhasuni completes.

After completing the custom of Dekhasuni they fix the date of the marriage. In the beginning that functions is done by the old man of the society. However, the Brahmin does it from the help of lunar calendar. They prefer to organize the marriage sacrament in full moon night. Marriage ceremony is organized for the nighttime and they do this work only at night. Then, necessary ornaments are bought, dresses are made, houses are decorated, food grains 
are managed and the process of marriage is taken ahead. The neighbors and the relatives are invited by both boys and girls sides. The relatives and the villagers of the boy's side participate in the marriage procession.

Before the procession of the marriage, some functions are done in both sides. At first, their marriage with the mango trees is done as an important ritual. In this process brother in law (sister's husband), takes the bride and the bridegroom both in a place where there is a mango tree. Then, the bridegroom or the bride digs the mud, puts some water there, makes the mud and brings it at home. Breaking of the earthen plate with the leg also is done. This mud is kept at the courtyard, where the bride sits for Sinduradana function in the following day. This function is done in both the boy's and the girl's side. However, the custom of taking mud at home is done only from the girl not from the boy. In this occasion Gidaris sing the song.

Kasakuti is other function that is done one day earlier than the marriage day in both sides. Some rice is grinded in the mortar and again the flour is made. Then it comes the term of making Kasakuti. They mix this flour in mustard oil with Hardi and polish the face, hands and feet by both the boy and the girl. This function is called Kasakuti. Motha a kind of herb is mixed in Kasakuti for the scent. A couple of kids are massacred in the name of Thakurjee Maharaj in this day. The Gidaris sing the song in this occasion. Gramdhami is also worshipped in this occasion. Then it comes the term of worshipping Gramdevata. Gramdevata is worshipped in the spot if the Than is near from the house. In the case of remaining it far from the house, it is remembered and worshipped from the home. Decoration of Maruwa and Dalsaji is also done in this day. Hence, Dalsaji is a process of decoration of the basket, which is taken at the girls house with the gifts for the boy.

The marriage procession goes towards the girl's house at the day of marriage. The boy walks in the procession with his relatives, neighbors and friends. The women sing and dance with enjoyment at the boy's house. The boy needs to give them 18 pieces of nuts for their songs. They have the system of playing Ratauly also at the boys house. The marriage function is organized only for the nighttime and the women of the boy's side sing and dance 
at the boy's house at night. It is said Ratauly as the time of its performance. It is said Kamkari in Rajvamshi language. Jodani Dagani is also done for the women to liberate her.

Rajvamshi bridegroom takes musical instruments in the occasion of marriage. In the beginning Chamars used to play Dhole (big drum) in this occasion, but now the system of playing band and other kind of sound system is popular. They do not have racial musical instruments. Therefore, they hire the music man from other cultural groups. Now a day the system of renting band party is increased. They take a Bhar with them in this occasion. It is a big Bhar which is called Sansani Bhar. They keep some beaten rice, curd, a kind of banana called Kurkuche and a pot of mustard oil in the Bhar. When they reach to the girl's house, the Laganiya Bhar is given to the girl's relative. The relatives of the girl and the boy joke and exchange their basket full of ornaments and clothes and the Gidaris sing the song. Gidaris get 18 pieces of nuts again in this occasion. Then, the bridegroom is taken out from the vehicle and he is kept on a lap of Laganiya. Some Gajal and Kasa is painted in the face and the hands of the bridegroom again there.

The bridegroom wears Pagari and Mor. Hence, Mor is a kind of crown which is decorative with feathers and colorful plastic objects. It is made at the time of marriage ceremony. Then the boy tries to go inside to take the girl out. However, the brother of the girl catches his clothes. The bridegroom needs to give him a set of clothe to become free from him. Then he goes inside the house and takes out the girl catching her in her eldest finger of the right hand. Then they do the function of Kumara Chumana. In this occasion the boy is given Duba grass, curd, banana and paddy grain in his hand. After that, five people of the girl's side give the Tika of curd to the fore head of bridegroom. Then it comes the term of girls Chumana. In this function, the father and the relatives of the boy give a set of clothes and ornaments to the girl. The Tika of the curd is given to the girl also. After that the boy and the girl are taken round the Mandapa by their sister in law (sisters husband) keeping them in their back. Then the donation of a plate, pot and ornament is done, which is like the Kanyadana rite of other community. Then Sindura Dana and Kangan are done. In Kangan rite, a little flour of the paddy grain is wrapped in two mango leaves and given both to the boy and girl. They tie it in their hands. In the same way, Sindura Dana is done standing on the heap of Thimka soil. 
After Sindura Dana, the relatives of the girl's side behave the boy respectfully. He is taken inside the house and given rice pudding and banana. However, the relatives of the both side sing each other. They ask question and answer in the style of song. The participants of marriage procession are also given food. Meat, beaten rice, sweet and curd are the main items of the food that are given to the guests in this occasion. They make a stage of marriage in the girl's house. However, they use banana plant instead of bamboo to make the stage.

Lokani are the relatives who participate in the procession of marriage. They are counted in the occasion of marriage and the father and the mother of the girl give them a Dhoti each. Father, uncles and grand fathers near in relation are given Dhoti. Others are not given gifts like this. The people who were left to give Chumana at the first day come there in the next day for Chumana. The bride and the bride groom are kept in the court yard of the girls' house and they are given some gifts in this occasion. Then the process of marriage completes in the girls house. Then, it comes the term of the functions that are done in the boy's house.

At least one Lokani goes with the girl in returning of marriage procession. Then he returns the following day with the girl. They need to send a Bhar with the girl to the girl's side. In the same, the boy also goes with her and takes the souvenirs for the girls. In the same way, the girl returns home after some days with the Bhara. They need to carry a Bhar with them in the first year in each occasion they go and return to the house and the father's house.

The last sacrament that Rajvamshi people do is the death sacraments. At first, the villagers are informed when a person dies in a family. The dead body is not taken out from the house at the time of the death. When the villagers and relatives present at this house, they clean the dead body with water and soap and the mustered is polished in it. Then the villagers and the relatives make an Arthi to take the dead body to the riverside. They do Kirtan in the way of death procession. Each people bring two meters of white cloth while going to the death procession. They offer it in the name of dead person and that is also burnt with the dead body.

Rajvamshi people have the system of burning dead body. However, they do not take the dead body far for disposal. They prefer to dispose it in the riverside near the village. 
Some of them bury it in some occasions. In general, the child, poor and died in natural disasters are buried. They do not have separate burials and they bury the dead body at the side of the river.

A bundle of dried grass is taken from the roof to burn the dead body. Firewood is also managed for it. An iron pot is kept on the dead body in its procession towards the river. It is done for the protection of the dead body from ghost and evil souls. Banana and rice is offered before taking it to the river for disposal. All his essentials are taken with the dead body and they are burnt. Rajvamshi people shave their hair clean and tie a piece of white cloth in their neck at the period of Ashocha. There are some restrictions in food and clothes in this occasion. According to their traditional custom, the son of the dead person is responsible to do death sacrament for its salvation. Among others, the eldest son is more responsible for death sacrament. At the time of Ashocha they do not eat salt, bailed paddy rice, mustard oil, meat and alcohol. They hang a piece of white clothes in the neck which is called Hilka and that is a symbol of keeping Ashocha. They can walk here and there in such occasions. Instead of food and drinks, they do not have more restrictions in it.

After the fire disposal of dead body, Rajvamshi people do not go to the river side for three days. At the third day of the disposal, they go to the riverside and bring some remainings of the disposal to carry it up to Ganga River. They consider Ganga River as the holiest river and take the remains of the dead body up to there. Tinasnan Bidhi is done at the third day in the name of dead person. The place of burning dead body is cleaned with water at that day. In the death sacrament, there are not more Bidhis up to the 4th day. However, Pindadana is done on 4th day and the 10th day of the death event. They have to go to the river for Pindana where the dead body is disposed. In the case of difficulties to reach up to the river regularly for Pindadana, they can perform this duty in a field near their houses also. They need Brahmin to offer Pinda in the name of dead person. They have their own Maithili Brahmin to perform death rite. Such Brahmins are not invited to perform other sacraments. The daily Pindadana that is offered in the name of dead person is called Sheshan. Rajvamshi people have different Brahmins to perform death sacraments in the rivers and the house. Both of them have given the separate duties. The Brahmin for the river is called Kantha and he is 
invited to offer Pindas in the field or river. Other kind of priest who performs Shradha at home is called Puretiya and he helps to perform the death rites at home.

Rajvamshi people complete their Ashocha ceremony in the 12th day of the death event. They shave their hair clean at that day and offer some food and cash to the priest in the same day in the name of the dead person. The Puretiya reads Mantras according to the Vedic Bidhi and gets some goods and cash. According to a custom for that day they need to offer Pinda at the third day of the death. At the same day, a room of the house is cleaned with cows dung and water to offer the food to the dead person. After that, the cooked food is offered to it. They think the dead person becomes a Preta and eats the offered food of that day. In the same way the steps seen in the sand kept in the room also symbolizes the entrance of soul in other creatures. For example if a cat is seen in the room or the footprint of the cat is seen, then it is believed that the soul became a cat. In the same if a snake is seen in the room, it became a snake. It is a traditional belief of Rajvanshi community.

The thirteenth day of the death event is much more important in Rajvamshi community. The daughter of the dead person should bring a Bhara with a kid on the 12th day of the death case. The food items are offered in the name of dead person and that is eaten. In the same way, the kid that the daughter brings is massacred in the name of dead person. The son and other family members of the dead person eat meat of this kid. In the case of dying male person, he kid is brought and she kid is brought in the case of dying the female.

The 12th day of the death event is much more important in Rajvamshi culture. They end Ashocha from that day after donating food grains, clothes and cash to the priest. A party is also given to the relatives and the Brahmins. All the rites and rituals are completed according to the Hindu rules. The donations are given in the form of Panchadana and Anekadana to the Brahmin. Some of them have the system of doing Shradha once a year. They offer water in the name of dead person in each Chaturdashi of Sorashradha. They have the system of doing Tirthashraddha also in the name of dead person. Gaya Shradha is popular among other Tirtha Shraddha. 


\section{Conclusion}

Rajvamshis reside mainly in eastern Nepal in their traditional villages. They are divided in different groups as Gotras and types. Bengali Rajvamshi and Khota Rajvamshi are their main divisions. Their Gotras are four in number namely Dhaneswara, Kasyap, Bharadwaj and Sandip Gotras. However they do not have big differences in their customs and traditions. They worship Thakurjee and Devis. They celebrate different kind of Hindu feasts and festivals.

Rajvamshi people of Nepal perform different kind of sacraments in their life time. However, they do not have more sacraments like other group of Hindu people. Chhati, marriage and death are main cycle of their life. These sacraments are compulsory too. Chhati is performed on the sixth day of a child birth. The room of the new born baby and it's mother is cleaned in this occasion and the elder woman of the family provides the name of new born baby in such occasion. In the same way other sacrament is marriage in this society. They practice different kind of marriage in the society. However, arrange marriage is preferable in the society. Remarriage, widow marriage and early marriage system is also accepted in traditional way. The last sacrament that the Rajvamshi society practices is death ceremony. They perform it according to the Hindu custom. Panchadana and Anekadana is done in the name of dead person and Ashoch is completed after 12th day of the death event. Tirtha Shradha system is also popular in this society. In this way Rajvamshi people perform different kind of sacraments based on Hindu system. Maithili Brahmin is responsible to perform sacraments in this society.

\section{REFERENCES}

Amatya, Saphalya. (1983). Some Aspects of Cultural Policies in Nepal, Paris: UNESCO.

Bista, DB. (1968). People of Nepal, Kathmandu: Ratna Pustak Bhandar.

Crooke, Sir William. (1957 AD). The Tribes and Caste in North Western Proveniences and Oudh, Allahabad: Cosmo Publication vol. 3.

---. (1973). The Native Races of India: Races of Northern India, Delhi: Cosmo Publication.

Dahal Peshal and Som Prasad Khatiwada. (2059 BS). Nepali Samaj ra Samskriti, Kathmandu: MK Publishers and Distributors. 
Dahal, DR. (2036 BS). Dhimal Lok Jivan, Kathmandu: Royal Nepal Academy.

Dalton, ET. (1978 AD). Tribal History of Eastern India, New Delhi: Cosmo Publication.

Diwas, Tulsi and Others. (2007 AD). The Intangible Cultural Heritage of Nepal: for Further Directions, Kathmandu: UNESCO.

Diwas, Tulsi. (2039 BS). Dhimal Lok Dharma ra Samskriti, Kathmandu: Royal Nepal Academy.

Gautam R and Ashok Thapamagar. (1994 AD). Tribal Ethnography of Nepal (vol. $2^{\text {nd }}$ ), Delhi: Book Faith India.

Khatiwada, SP and Kamala Dahal. (2067 BS). Cultural Tourism of Nepal, Kathmandu: MK Publishers.

Krishna LA and Balaratnam LK. (1961 AD). Anthropology in India, Bimbay: Bharatiya Bidhya Bhawan.

Kshetry Ganesh and Som Prasad Khatiwada. (2054 BS). Hindu Samaj ra Dharma, Biratnagar: Shiva Prakashan.

Lamichhane, BP. (2063 BS). Samskriti ra Samskaras, Varanashi: Anusthan Prakashan.

Maun, Praphulla Kumar. (1968 AD). Tharu Lokgita, Biratnagar: Purvanchal Pustak Bhandar.

Mishra, Tarakanta. (1985 AD). Maithili Lok Sahityaka Adhyayan, Delhi: Janaki Prakashan.

Panta, SD. (2041 BS). Jhapaka Adibashi, Kathmandu: Shaja Prakashan.

Ramakanta. (1968 AD). Indo-Nepalese Relations, New Delhi: S. Chand and Company.

Regmi, Rishideshab Raj. (1985 AD). Cultural Patterns and Economic Change, Varanasi: Arya Bhusan Press.

Risley, HR. (1992 AD). The Tribes and Caste of Bengal, Calcutta, vol. 11.

Shrestha, Keshab Kumar (2068 BS), Nepalka Rajvamshi, Kathmandu: Nikesh Shrestha.

Simha, Praphulla Kumar Mauna. (2025 BS). Tharu Lokagita, Biratnagar: Purvanchal Pustak Bhandar.

Waddel, LA. (1975). Tribes of the Brahmaputra Valley reprint. Delhi. 